\title{
PEMBERIAN IKAN GABUS DALAM PENYEMBUHAN LUKA PERINEUM PADA IBU POST PARTUM
}

\author{
Mayang Wulan ${ }^{1 *}$, Sri Juliani², Nuriah Arma $^{3}$, Ivansri Marsaulina ${ }^{4}$, Mila Syari ${ }^{5}$ \\ 1,2,3,4,5Prodi D4 Kebidanan Institut Kesehatan Helvetia \\ *Koresponden E-mail : mayangwulan@helvetia.ac.id
}

\section{ABSTRACT GIVING COCK FISH ON PERINEUM WOUND HEALING IN POST PARTUM WOMEN IN CLINIC NIAR MEDAN}

Background: Perineal wound is a tear that occurs in the perineum during delivery and occurs in almost all first deliveries and not infrequently also in subsequent deliveries. Care and proper nutrition, the healing process will be faster and avoid the incidence of infection due to perineal wounds. In 2020 in America, of the 26 million women who gave birth, $40 \%$ experienced perineal rupture. In Asia, the problem of perineal tears is quite a lot in the community, $50 \%$ of the incidence of perineal tears in the world occurs in Asia.

Purpose: This study is to determine the effect of cork fish on the healing of perineal wounds in postpartum mothers at the Niar Clinic in Medan.

Methods: The design in the study is a quasi-experimental method (Quasi Experiment Design) Whith Control Group with a Post Test Design approach. The population in this study were 20 people with the sampling technique using purposive sampling technique, the number of samples in this study amounted to 20 people. Data analysis used descriptive and bivariate analysis.

Results: Showed that the data for postpartum mothers who had perineal injuries who were given snakehead fish and not snakehead fish were not normally distributed with a value of $\rho$ value $0.000<0.05$. Based on the test results there was an effect of snakehead fish on healing perineal wounds with a sig $=0.004<0.05$.

Conclusion: this study is that there is the effect of giving cork fish on the healing of perineal wounds on the healing of perineal wounds in post partum mothers at the Niar Clinic in Medan.

Suggestion The results of this study can be used for postpartum mothers who experience perineal injuries to consume a high protein source, namely snakehead fish.

Keywords : Fish Cork, Perineal Wound Healing

\section{ABSTRAK}

Latar Belakang: Luka perineum adalah robekan yang terjadi pada perineum sewaktu persalinan dan terjadi pada hampir semua persalinan pertama dan tidak jarang juga pada persalinan berikutnya. Perawatan dan nutrisi yang tepat, proses penyembuhan akan semakin cepat dan terhindar dari kejadian infeksi akibat dari luka perineum. Pada tahun 2020 di Amerika dari 26 juta ibu bersalin, terdapat $40 \%$ mengalami ruptur perineum. Di Asia masalah robekan perineum cukup banyak dalam masyarakat, $50 \%$ dari kejadian robekan perineum di dunia terjadi di Asia. Tujuan Penelitian: Tujuan penelitian ini untuk mengetahui Pengaruh Pemberian Ikan Gabus Terhadap Penyembuhan Luka Perineum Pada Ibu Post Partum Di Klinik Niar Medan.

Metode Penelitian: Desain dalam Penelitian adalah metode eksperimen semu (Quasi Eksperiment Design) Whith Control Group dengan pendekatan Post Test Design. Populasi dalam penelitian ini sebanyak 25 orang dengan teknik pengambilan sampel menggunakan teknik purposive sampling, jumlah sampel dalam penelitian ini berjumlah 20 orang. Analisa data menggunakan analisis deskriptif dan bivariat.

Hasil: peneitian menunjukkan bahwa data ibu post partum yang mengalami luka perineum yang diberikan ikan gabus dan tidak diberikan ikan gabus tidak terdistibusi normal dengan nilai $\rho$ value $0,000<0,05$. Berdasarkan hasil uji ada pengaruh pemberian ikan gabus terhadap penyembuhan luka perineum dengan nilai sig $=0,004<0,05$.

Kesimpulan: penelitian ini yaitu ada Pengaruh Pemberian Ikan Gabus Terhadap Penyembuhan Luka Perineum Terhadap Penyembuhan Luka Perineum Pada Ibu Post Partum Di Klinik Niar Medan.

Saran Hasil peneltian ini dapat digunakan untuk para ibu post partum yang mengalami luka perineum untuk mengkonsumsi sumber protein yang tinggi yaitu ikan gabus.

Kata Kunci : Ikan Gabus, Penyembuhan Luka Perineum 


\section{JKM (Jurnal Kebidanan Malahayati),Vol 7,No.4.Oktober 2021, \\ ISSN (Print) 2476-8944 ISSN (Online) 2579-762X, Hal 766-771}

\section{PENDAHULUAN}

Robekan jalan lahir terjadi pada persalinan dengan trauma. Pertolongan persalinan yang semakin manipulatif dan traumatik akan memudahkan robekan jalan lahir dan karena itu dihindari memimpin persalinan pada saat pembukaan serviks belum lengkap. Robekan jalan lahir biasanya akibat episiotomi, robekan spontan perenium, trauma forseps, atau vakum ekstraksi, atau karena versi ekstraksi (Imron et al., 2016)

Menurut data World Health Organization (WHO) angka robekan perineum diperkirakan mencapai 6,3 juta pada tahun (2020). Di Amerika dari 26 juta ibu bersalin, terdapat $40 \%$ mengalami ruptur perineum. Di Asia masalah robekan perineum cukup banyak dalam masyarakat, $50 \%$ dari kejadian robekan perineum di dunia terjadi di Asia (Kiromah et al., 2018).

Proses untuk mempercepat penyembuhan luka perineum terdapat beberapa cara, salah satunya adalah melalui perbaikan gizi dengan mengkonsumsi makanan tinggi kalori dan protein. Sumber umum protein adalah daging, susu, roti, sereal, telur, ikan, kacang-kacangan dan biji-bijian. Ikan gabus (Channa striata) merupakan salah satu jenis ikan yang dapat meningkatkan daya tahan tubuh karena mengandung protein dan albumin yang tinggi. Daging ikan gabus mengandung $70 \%$ protein dan $21 \%$ albumin. Di samping itu, daging ikan gabus juga mengandung asam amino yang lengkap serta mikronutrien zinc, selenium dan iron. Kandungan lain dalam daging ikan gabus adalah alisin, alil sulfide dan furostanolglikosida (Purnani, 2019).

Kebutuhan paling utama yang harus dipenuhi oleh ibu post partum dengan adanya luka adalah nutrisi yang baik untuk sistem imun dan penyembuhan luka. Nutrisi yang dibutuhkan untuk penyembuhan luka yaitu mengkonsumsi makanan yang tinggi akan protein. Protein di dapatkan pada makanan, daging dan ikan. Semua jenis ikan adalah sumber protein yang sangat baik. Ikan gabus diketahui sebagai ikan dengan kandungan gizi dan protein yang lebih banyak dari ikan jenis lain seperti bandeng. Selain itu, keunggulan ikan gabus mempunyai protein yang tinggi, kadar protein per 100 gram ikan gabus setara dengan ikan bandeng (Violita, 2019).

Dari hasil penelitian Violita (2019) hasil perhitungan nilai rata-rata setelah di berikan ikan gabus lebih kecil dari pada nilai rata-rata tanpa diberikan ikan gabus. Pada analisis bivariate menunjukkan bahwa adanya efektifitas di berikan ikan gabus terhadap penyembuhan luka perineum (Violita, 2019). Berdasarkan survei awal pada bulan
September yang dilakukan di Klinik Niar Medan pada ibu post partum. Dari buku rawatan ibu bersalin terdapat 7 orang ibu post partum yang mengalami luka perineum, terdapat sebanyak 3 orang ibu post partum yang mengalami luka perineum yang mengkonsumsi ikan gabus dan sebanyak 4 orang ibu post partum yang mengalami luka perineum yang tidak mengkonsumsi ikan gabus. Berdasarkan hasil wawancara ibu post partum yang tidak mengkonsumsi ikan gabus dikarenakan ibu post partum tidak tahu akan manfaat ikan gabus terhadap penyembuhan luka perineum.

\section{METODE PENELITIAN}

Desain yang digunakan adalah metode eksperimen semu (Quasi Eksperiment Design) dengan pendekatan Post Test Control Group Design, dimana peneliti tidak memberikan perlakuan pada kelompok kontrol dan untuk kelompok intervensi diberikan ikan gabus yang telah diolah dengan cara dikukus seberat $100 \mathrm{gram}$ perhari selama 8 hari. Secara spesifik, 100 gram ikan gabus mengandung 69 gram kalori, 25,5 gram protein dan 1,7 gram lemak, berdasarkan penelitian Fitriyani (2013) jumlah protein tersebut yang diperlukan dalam penyembuhan luka perhari.

Pada kedua kelompok dilakukan Post Test yaitu dilakukan pengukuran penyembuhan luka dengan instrumen REEDA (Redness, Edema, Ecchymosis, Discharge, Approximation) dengan kategori cepat $<6$ Hari, Sedang $6-7$ Hari, lama $>7$ Hari.

Lokasi penelitian ini dilakukan di Klinik Niar Medan. Waktu penelitian ini mulai bulan Mei September. Sampel dalam penelitian menggunakan Purposive sampling yaitu ibu post partum hari pertama yang mengalami luka perineum sebanyak 20 orang di Klinik Niar Medan. Adapun kriteria inklusi dalam penelitian ini adalah ibu post partum yang mengalami luka perineum dengan kriterian ruptur perineum derajat II, bersedia menjadi responden dalam penelitian dan yang tinggal menetap di wilayah Klinik Niar. Uji bivariat dalam penelitian ini menggunakan uji wilcoxon rank test untuk melihat pengaruh pemberian ikan gabus terhadap penyembuhan luka perineum.

\section{HASIL DAN PEMBAHASAN}

Berdasarkan hasil penelitian yang dilakukan di klinik Niar didapatkan hasil sebagai berikut: 
Tabel 1.

Distribusi Frekuensi Umur dan Paritas lbu Post Partum Di Klinik Niar Medan

\begin{tabular}{lcc}
\hline \multicolumn{1}{r}{ Variabel } & F & $\%$ \\
\hline Umur & & \\
$<20$ tahun & 2 & 10 \\
$20-35$ tahun & 18 & 90 \\
$>35$ tahun & 0 & 0 \\
Paritas & & \\
Primipara & 9 & 45 \\
Multipara & 11 & 55 \\
Grandemultipara & 0 & 0 \\
\hline \multicolumn{1}{r}{ Total } & 20 & 100 \\
\hline
\end{tabular}

Pada tabel di atas tampak distribusi frekuensi responden berdasarkan umur ibu post partum yang mengalami luka perineum di Klinik Niar Medan. Diketahui bahwa dari 20 orang ibu post partum (100\%) mayoritas ibu post partum yang berumur 20-35 tahun sebanyak 18 orang $(90 \%)$ sedangkan minoritas ibu post partum yang berumur $<20$ tahun sebanyak 2 orang (10\%).

Berdasarkan paritas ibu post partum yang mengalami luka perineum di Klinik Niar Medan. Diketahui bahwa dari 20 orang ibu post partum $(100 \%)$ mayoritas ibu post partum yang primipara sebanyak 9 orang (45\%) sedangkan minoritas ibu post partum yang multipara sebanyak 11 orang $(55 \%)$.

Tabel 2.

Distribusi Frekuensi Responden Berdasarkan lbu Post Partum Yang Mengalami Luka Perineum Yang Diberikan Ikan Gabus Dan Yang Tidak Diberikan Ikan Gabus Di Klinik Niar Medan

\begin{tabular}{|c|c|c|}
\hline \multirow{2}{*}{ Karakteristik } & \multicolumn{2}{|c|}{ Jumlah } \\
\hline & $\mathbf{F}$ & $\%$ \\
\hline Penyembuhan Luka Perineum Yang Diber & & \\
\hline Cepat & 7 & 70 \\
\hline Normal & 3 & 30 \\
\hline Lama & 0 & 0 \\
\hline Penyembuhan Luka Perineum Yang Tidak & & \\
\hline Cepat & 0 & 0 \\
\hline Normal & 3 & 30 \\
\hline Lama & 7 & 70 \\
\hline Total & 10 & 100 \\
\hline
\end{tabular}

Distribusi frekuensi responden berdasarkan ibu post partum yang mengalami luka perineum yang diberikan kukusan ikan gabus di Klinik Niar Medan. Diketahui bahwa dari 10 orang ibu post partum (100\%) mayoritas ibu post partum yang penyembuhan luka perineum cepat sebanyak 7 orang $(70 \%)$ sedangkan minoritas ibu post partum yang penyembuhan luka perineum normal sebanyak 3 orang $(30 \%)$.
Distribusi frekuensi responden berdasarkan ibu post partum yang mengalami luka perineum yang diberikan kukusan ikan gabus di Klinik Pratama Niar Medan. Diketahui bahwa dari 10 orang ibu post partum (100\%) mayoritas ibu post partum yang penyembuhan luka perineum lama sebanyak 7 orang $(70 \%)$ sedangkan minoritas ibu post partum yang penyembuhan luka perineum normal sebanyak 3 orang $(30 \%)$.

Tabel 3.

Hasil Uji Normalitas Shapiro-Wilk Pengaruh Pemberian Ikan Gabus Terhadap Penyembuhan Luka Perineum Pada Ibu Post Partum Di Klinik Niar

\begin{tabular}{lccc}
\hline \multirow{2}{*}{ Kelompok } & \multicolumn{3}{c}{ Shapiro-Wilk } \\
\cline { 2 - 4 } & Statistic & Df & Sig. \\
\hline Intervensi & 0,594 & 10 & 000 \\
Kontrol & 0,594 & 10 & 000 \\
\hline
\end{tabular}

Hasil uji normalitas data di atas dengan menggunakan uji shapiro wilk maka dapat di simpulkan bahwa data ibu post partum yang mengalami luka perineum yang diberikan ikan gabus di dapatkan nilai $\rho$ value (sig) yaitu 0,000 yang mana lebih kecil dari 0,05 atau Ho diterima 


\section{JKM (Jurnal Kebidanan Malahayati),Vol 7,No.4.Oktober 2021, \\ ISSN (Print) 2476-8944 ISSN (Online) 2579-762X, Hal 766-771}

atau dapat disimpulkan bahwa distribusi pada data tersebut adalah data tidak terdistribusi normal sedangkan data ibu post partum yang mengalami luka perineum yang tidak diberikan ikan gabus didapatkan nilai $\rho$ value (sig) yaitu 0,000 yang mana lebih kecil dari 0,05 atau Ho diterima atau dapat disimpulkan bahwa distribusi pada data tersebut adalah data tidak terdistribusi normal. Maka dari itu, jika data tidak terdistribusi normal maka langkah selanjutnya uji non parametrik dengan uji wilcoxon.

Tabel 4.

Hasil Uji Wilcoxon Pengaruh Pemberian Ikan Gabus Terhadap Penyembuhan Luka Perineum Pada Ibu Post Partum di Klinik Niar Medan

\begin{tabular}{llcc}
\hline & & N & Mean Rank \\
\hline Kontrol - Intervensi & Negative Ranks & $0^{\mathrm{a}}$ & .00 \\
& Positive Ranks & $10^{\mathrm{b}}$ & 5.50 \\
& Ties & $0^{\mathrm{c}}$ & \\
& Total & 10 & \\
\hline
\end{tabular}

Hasil dari pemberian ikan gabus dari kelompok yang diberikan dan yang tidak diberikan terdapat 10 nilai positif $(\mathrm{N})$ yang artinya dari 20 responden 10 diantaranya mengalami peningkatan penyembuhan luka perineum, dengan nilai rata-rata $5,50 \%$.

Tabel 5.

Distribusi Frekuensi Pengaruh Pemberian Ikan Gabus Terhadap Penyembuhan Luka Perineum Pada Ibu Post Partum Di Klinik Niar Medan

\begin{tabular}{cc}
\hline & Diberikan - Tidak Diberikan \\
\hline$Z$ & $-2.889^{a}$ \\
Asymp. Sig. (2-tailed) & .004 \\
\hline
\end{tabular}

Pada uji wilcoxon dapat diketahui bahwa dari tabel di atas di dapatkan nilai sig $=0,004$ dimana $<0,05$ maka dapat disimpulkan bahwa ada Pengaruh Pemberian Ikan Gabus Terhadap Penyembuhan Luka Perineum Pada lbu Post Partum Di Klinik Niar Medan.

\section{PEMBAHASAN}

Penyembuhan Luka Perineum Pada lbu Post Partum Kelompok Intervensi di Klinik Niar Medan

Berdasarkan hasil penelitian menunjukkan bahwa ibu post partum yang mengalami luka perineum yang diberikan ikan gabus di Klinik Niar Medan. Diketahui bahwa dari 10 orang ibu post partum (100\%) mayoritas ibu post partum yang penyembuhan luka perineum cepat sebanyak 7 orang $(70 \%)$ sedangkan minoritas ibu post partum yang penyembuhan luka perineum normal sebanyak 3 orang $(30 \%)$. Pada ibu post partum yang mengalami luka perineum terdapat peningkatan frekuensi penyembuhan luka perineum sehingga dapat disimpulkan pemberian ikan gabus yang telah diolah dengan cara dikukus seberat 100 gram perhari selama 7 hari sangat efektif untuk penyembuhan luka perineum.

Proses untuk mempercepat penyembuhan luka perineum terdapat beberapa cara, salah satunya adalah melalui perbaikan gizi dengan mengkonsumsi makanan tinggi kalori dan protein. Sumber umum protein adalah daging, susu, roti, sereal, telur, ikan, kacang-kacangan dan biji-bijian. Ikan gabus (Channa striata) merupakan salah satu jenis ikan yang dapat meningkatkan daya tahan tubuh karena mengandung protein dan albumin yang tinggi. Daging ikan gabus mengandung $70 \%$ protein dan $21 \%$ albumin. Di samping itu, daging ikan gabus juga mengandung asam amino yang lengkap serta mikronutrien zinc, selenium dan iron. Kandungan lain dalam daging ikan gabus adalah alisin, alil sulfide dan furostanolglikosida (Purnani, 2019).

Menurut asumsi penelitian berdasarkan penelitiaan yang dilakukan Sampara (2020) dengan pemberian ikan gabus secara rutin dengan jumlah yang tepat dapat mempercepat penyembuhan luka perineum pada ibu post partum. Hal ini dikarenakan ikan gabus memiliki kandungan albumin yang tinggi (Sampara et al., 2020). 
Konsumsi ikan gabus salah satunya di latar belakangi oleh umur responden. Umur yang cukup matang menyebabkan responden pada kelompok perlakuan yang mendapat ikan gabus mampu menyadari pentingnya mengkonsumsi ikan gabus sebagai alternatif pengobatan yang mempercepat penyembuhan luka yang dialaminya. Hal ini mempengaruhi pula ketaatannya dalam mengkonsumsi ikan gabus selama penelitian. Dilihat dari responden yang mengkonsumsi ikan gabus dinyatakan sembuh pada hari ke-5 terlihat dari distribusi frekuensi penyembuhan luka perineum yang diberikan ikan gabus pada ibu nifas kategori cepat $(<6$ hari) sebanyak 7 orang $(70 \%)$. Karena itu, disarankan kepada ibu yang baru melahirkan yang mengalami luka perineum untuk mengkonsumsi ikan gabus secara teratur setiap hari agar proses penyembuhan luka perineum dapat berlangsung dengan cepat.

\section{Penyembuhan Luka Perineum Pada lbu Post Partum Kelompok Kontrol di Klinik Niar Medan}

Berdasarkan hasil penelitian menunjukkan bahwa ibu post partum yang mengalami luka perineum yang tidak diberikan ikan gabus di Klinik Pratama Niar Medan Tahun 2020. Diketahui bahwa dari 10 orang ibu post partum (100\%) mayoritas ibu post partum yang penyembuhan luka perineum lama sebanyak 7 orang $(70 \%)$ sedangkan minoritas ibu post partum yang penyembuhan luka perineum normal sebanyak 3 orang $(30 \%)$.

Penelitian ini sejalan dengan penelitian yang dilakukan oleh Muhammad Reza Setiawan, Nurdiana Dewi dan Ika Kustiyah Oktaviyanti (2015) Hasilnya menunjukkan bahwa jumlah neokapiler mencapai puncak pada hari ke-5. Rerata jumlah neokapiler pada tiap kelompok berturut 12; 16,5 ; 18,5 dan 6. Uji Anova 2-jalur dan uji post hoc LSD menunjukkan adanya perbedaan bermakna antara kontrol negatif dan ekstrak ikan haruan. Berdasarkan hasil penelitian, disimpulkan bahwa pemberian ekstrak ikan haruan secara bermakna meningkatkan jumlah neokapiler pada proses penyembuhan luka (Setiawan et al., 2015).

Ikan gabus merupakan salah satu jenis ikan yang banyak digunakan oleh masyarakat untuk penyembuhan luka terutama luka pasca operasi, luka bakar dan setelah persalinan, karena albumin utama dalam ikan gabus adalah protein atau albuminnya yabg cukup tinggi dan juga albumin merupakan protein terbanyak dalam plasma , sekitar $60 \%$ dari total plasma protein dengan nilai normal 3,3-5,5 g/dl albumin juga didapatkan pada ruang ekstrasel $40 \%$ terdapat pada plasma dan 60\% ekstrasel (Intiyani et al., 2018).
Menurut asumsi penelitian dengan mengkonsumsi ikan gabus secara rutin dengan jumlah yang tepat dapat mempercepat penyembuhan luka perineum pada ibu post partum. Hal ini dikarenakan ikan gabus memiliki kandungan albumin yang tinggi. Albumin ini sangat penting dalam tubuh, karena dapat mempercepat pembentukan jaringan sel baru. Albumin juga berperan penting dalam proses penyembuhan luka. Dilihat dari responden yang tidak mengkonsumsi ikan gabus dinyatakan sembuh pada hari ke-8. Karena itu, disarankan kepada ibu yang baru melahirkan yang mengalami luka perineum untuk mengkonsumsi ikan gabus secara teratur setiap hari agar proses penyembuhan luka perineum dapat berlangsung dengan cepat.

\section{Pengaruh Pemberian Ikan Gabus Terhadap Penyembuhan Luka Perineum Pada lbu Post Partum di Klinik Niar Medan \\ Berdasarkan pada uji normalitas Shapiro-} wilk bahwa data ibu post partum yang mengalami luka perineum yang diberikan ikan gabus di dapatkan nilai $\rho$ value (sig) yaitu 0,000 dan data ibu post partum yang mengalami luka perineum yang tidak diberikan ikan gabus di dapatkan nilai $\rho$ value (sig) yaitu 0,000 dengan demikian dapat disimpulkan bahwa data tidak terdistribusi normal. Kemudian jika data tidak terdistribusi normal maka dilakukan uji wilcoxon yang dapat di ketahui nilai sig= 0,004 dimana $<0,05$ maka dapat di simpulkan bahwa ada Pengaruh Pemberian Ikan Gabus Terhadap Penyambuhan Luka Perineum Pada Ibu Post Partum di Klinik Niar Medan.

Penelitian ini sejalan dengan penelitian yang dilakukan oleh Evi Fitriyani dan Ika Meidy Deviarni (2013) Hasil nilai efektivitas tertinggi 1,53 didapat dari perlakuan albumin 60 gram terhadap parameter pH, Viskositas, stabilitas emulsi, warna, kecerahan, bau dan tekstur, sedangkan nilai terendah pada perlakuan albumin 20 gram dengan nilai efektivitas 0,35 . Dari hasil percobaan pada mencit menunjukkan bahwa perlakuan 60 gram memberikan waktu penyembuhan selama 4 hari, sementara perlakuan 20 gram dan 40 gram memberikan waktu penyembuhan selama 5 hari. Sehingga dapat disimpulkan bahwa terdapat pengaruh pemberian ikan gabus terhadap penyembuhan luka perineum pada ibu post partum di Klinik Pratama Niar Medan Tahun 2020 (Fitriyani \& Deviarni, 2013).

Ikan gabus mempunyai senyawa yang penting bagi tubuh, seperti protein dan beberapa mineral. Kadar protein ikan gabus mencapai 25,5\% dibandingkan protein ikan lainnya, albumin ikan 


\section{JKM (Jurnal Kebidanan Malahayati),Vol 7,No.4.Oktober 2021, \\ ISSN (Print) 2476-8944 ISSN (Online) 2579-762X, Hal 766-771}

gabus cukup tinggi mencapai $6,22 \%$ dan daging ikan gabus mengandung mineral seng dengan kadar 1,74 mg/100 gram. Ikan gabus jenis canna striata sangat kaya akan sumber albumin, salah satu jenis protein penting yang diperlukan tubuh manusia setiap hari. Sumber albumin ikan gabus sangat baik digunakan bagi penderita hipoalbumin (rendah albumin) dan penyembuhan luka pasca operasi maupun luka bakar. Bahkan, di daerah pedesaan, anak laki-laki pasca Khitan selalu dianjurkan mengkonsumsi ikan jenis ini agar penyembuhan lebih cepat, wanita habis melahirkan, dan pasien pasca operasi dianjurkan mengonsumsi untuk mempercepat penyembuhan luka (Fitriyani \& Deviarni, 2013).

Menurut asumsi penelitian protein pada ikan gabus mempunyai pengaruh terhadap penyembuhan luka dengan pemenuhan kebutuhan protein untuk pembentukan jaringan baru disekitar luka. Meskipun banyak faktor yang mempengaruhi, tetapi menjaga asupan nutrisi protein tinggi dengan ikan gabus lebih dominan dalam tubuh. Selain faktor nutisi, proses penyembuhan luka juga dipengaruhi oleh beberapa faktor lain diantaranya yaitu faktor usia dimana ibu post partum dengan luka perineum berada dalam usia reproduksi (20-35 tahun) memiliki mekanisme sel yang bekerja lebih cepat dan efektif terhadap penyembuhan luka. Selain umur, faktor paritas juga berpengaruh, ibu yang sudah mempunyai anak atau yang sudah pernah melahirkan seperti halnya ibu multipara akan berbeda dengan apa yang dirasakan atau dialami orang yang baru pertama melahirkan atau primipara karena pengalaman menghadapi situasi tersebut akan membuat seseorang lebih siap dan mandiri dalam melakukan pemenuhan nutrisi pasca melahirkan.

\section{SIMPULAN}

Ada pengaruh pemberian ikan gabus terhadap peyembuhan luka perineum pada ibu post partum di Klinik Niar Medan.

\section{SARAN}

Hasil peneltian ini dapat digunakan untuk para ibu post partum yang mengalami luka perineum untuk mengkonsumsi sumber protein yang tinggi yaitu ikan gabus.

\section{DAFTAR PUSTAKA}

Fitriyani, E., \& Deviarni, I. M. (2013). Pemanfaatan Ekstrak Albumin Ikan Gabus (Channa Striata) Sebagai Bahan Dasar Cream Penyembuhan Luka. IX.

Imron, R., Asih, Y., \& Indrasari, N. (2016). Buku Ajar Asuhan Kebidanan Patologi Dalam Kehamilan, Persalinan, Nifas Dan Gangguan Reproduksi.

Intiyani, R., Astuti, D. P., \& Sofiana, J. (2018). The 8 Th University Research Colloquium 2018 Universitas Muhammadiyah Purwokerto Pemberian Suplementasi Zinc Dan Ekstrak Ikan Gabus Untuk Implementation Of Zinc Supplement And Snake Head Fish Extracts The 8 Th University Research Colloquium 2018 Universit. 571-578.

Kiromah, N. Z. W., Lestari, S., \& Astuti, D. P. (2018). Penerapan Pemberian Madu Untuk Mempercepat Penyembuhan Luka Perineum Pada Ibu Post Partum.

Purnani, W. T. (2019). Perbedaan Efektivitas Pemberian Putih Telur Dan Ikan Gabus Terhadap Penyembuhan Luka Perineum Ibu Nifas. Journal Of Public Health Research And Community Health Development, 2(2), 126.

Https://Doi.Org/10.20473/Jphrecode.V2i2.12 190

Sampara, N., Sikki, Su., \& Aspar, R. (2020). Pengaruh Mengkonsumsi Ikan Gabus Terhadap Penyembuhan Luka Perineum Pada Ibu Nifas. Prosiding Seminar Nasional Kesehatan Masyarakat 2020, 1(1), 138-146.

Setiawan, M. R., Dewi, N., \& Oktaviyanti, I. K. (2015). Ekstrak Ikan Haruan (Channa Striata) Meningkatkan Jumlah Neokapiler Pada Penyembuhan Luka (Extract Of Haruan (Channa Striata) Increases Neocapillaries Count In Wound Healing Process). 14, No.1.

Violita, T. Y. V. (2019). Efektifitas Ikan Gabus Terhadap Penyembuhan Luka Perineum Pada Ibu Post Partum Di Wilayah Kerja Puskesmas Kalongan Kabupaten Semarang Tahun 2019. Universitas Ngudi Waluyo. 